\title{
USING ELECTRICAL RESISTIVITY METHODS TO MAP CAVE PASSAGES AND CONDUITS IN THE SAN SOLOMON SPRINGS KARSTIC AQUIFER SYSTEM, WEST TEXAS, USA
}

\author{
Lewis Land \\ National Cave and Karst Research Institute, 400-1 Cascades Ave., Carlsbad, NM, 88220, USA, lland@nckri.org \\ Michael Jones \\ National Cave and Karst Research Institute, 400-1 Cascades Ave., Carlsbad, NM, 88220, USA, mjones@nckri.org \\ George Veni \\ National Cave and Karst Research Institute, 400-1 Cascades Ave., Carlsbad, NM, 88220,USA, gveni@nckri.org
}

\begin{abstract}
Personnel with the National Cave and Karst Research Institute conducted a series of electrical resistivity (ER) surveys over and beyond mapped portions of Phantom Lake Spring Cave, currently the deepest underwater cave in the United States, and one component of the San Solomon Spring Group, a network of karstic springs in far West Texas. This work is part of a larger investigation of the regional hydrologic framework of the San Solomon Springs, and was motivated by concerns about the impact of new oil and gas operations on water resources and water quality in the region.
\end{abstract}

Most of the cave is partially or completely flooded with brackish water, and appears on ER profiles as a zone of low electrical resistivity. ER surveys show electrically conductive zones indicative of a flooded conduit more than $400 \mathrm{~m}$ beyond the farthest downgradient station in the mapped portion of the cave. A dye trace study conducted in 2013 demonstrated that water in Phantom Lake Spring Cave flows at an apparent velocity of $\sim 1000 \mathrm{~m} /$ day through conduits formed in Cretaceous limestone, eventually discharging from San Solomon Spring at Balmorhea State Park, six kilometers east of the cave entrance. Low resistivity anomalies identified on ER surveys conducted west of the park probably represent those flooded karstic conduits that provide the hydrologic link between Phantom Lake Spring Cave and San Solomon Spring.

\section{Background}

In 2016, news outlets announced the discovery of Alpine High, a large oil and gas complex in West Texas in the southwest corner of the Delaware Basin, near the junction of Culberson, Jeff Davis, and Reeves counties (Blackmon, 2016). The announcement was met with enthusiasm by stakeholders, as well as concern about the impact of the development on water resources and water quality in the region. The southwest edge of the basin contains the San Solomon Spring Group, a series of six karst springs that discharge groundwater from Cretaceous limestones along the northeast flank of the Davis Mountains. The springs and related groundwater provide water resources for much of the agricultural activity in the area. The main San Solomon Spring discharges into the pool at Balmorhea State Park, another important component of the local economy. The springs also provide habitat for several federally listed endangered species, including the Comanche Springs pupfish (Cyprinodon elegans), the Pecos gambusia (Gambusia nobilis), and the Phantom Lake springsnail (Tryonia cheatumi) (US Fish and Wildlife Service, 2013; Land and Veni, 2018).

The San Solomon Spring Group is located at the far western edge of the Edwards Plateau, one of the largest karst regions in the United States (Kastning, 1983; Figure 1). The San Solomon Spring area also lies within the boundaries of several regional investigations of the greater Edwards-Trinity Aquifer system, conducted over the past 26 years by the US Geological Survey (Barker et al., 1994; Kuniansky and Holligan, 1994; Barker and Ardis, 1996; Kuniansky and Ardis, 2004; Bumgarner et al., 2012; Thomas et al., 2013) and the Texas Water Development Board (e.g., Anaya, 2001; Mace et al., 2001; Anaya and Jones, 2009). However, previous research conducted by hydrologists at the University of Texas at Austin (e.g., LaFave and Sharp, 1987; Sharp, 2001; Sharp et al., 2003) indicates that the San Solomon Springs occupy a different hydrologic regime that has little to do with the Edwards-Trinity Aquifer. 


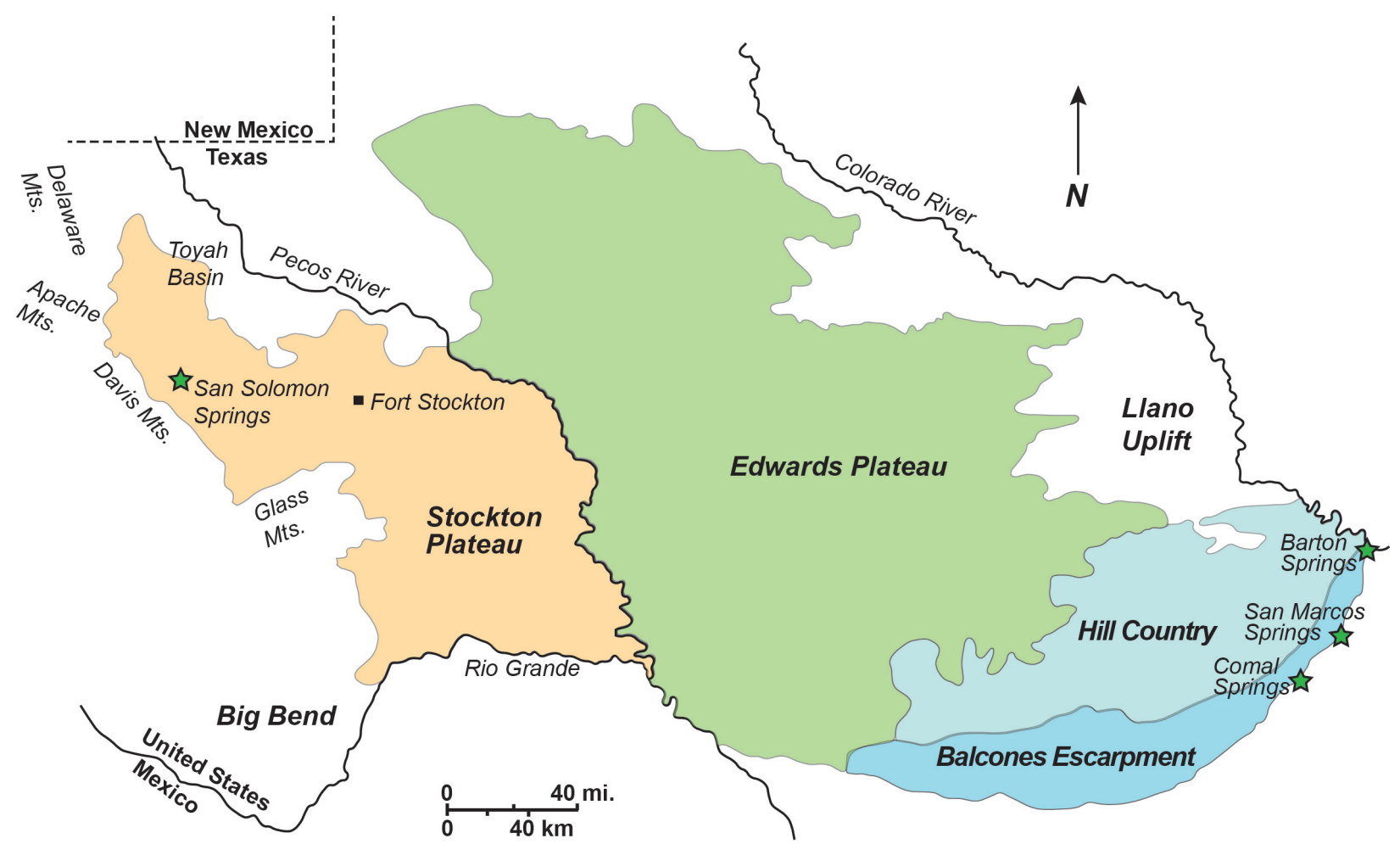

Figure 1. Physiographic map of south-central Texas. West of the Pecos River (Trans-Pecos region) the Edwards Plateau is sometimes referred to as the Stockton Plateau. The various components of the greater Edwards-Trinity Aquifer System are indicated by color shading (Land and Veni, 2018).

Based on geochemical and isotopic data (e.g., Chowdhury et al., 2004; Uliana et al., 2007), these studies conclude that discharge from the San Solomon Springs is fed by two sources of water: Cretaceous limestones and volcanic rock in the Davis Mountains a few kilometers to the south; and a more distant source, originating from groundwater recharge in alluvial basins to the west in central Culberson County (Figure 2). Groundwater in these alluvial basins then flows through Permian carbonates of the Capitan Reef complex in the Apache Mountains, and into Cretaceous rocks juxtaposed by faulting against the Capitan Reef carbonates in the subsurface (Figure 3). Groundwater first discharges from Phantom Lake Spring Cave, and subsequently from the five downgradient springs, including discharge from San Solomon Spring into the pool at Balmorhea State Park, six kilometers east of the cave entrance. This conceptual model thus defines a regional groundwater flow system that extends for more than 120 kilometers from west to east.

Other investigators have observed that there has been little analysis of hydraulic and geologic data to support these models of regional flow (Finch, 2018, written communi- cation). Investigations of the karstic nature of the aquifer are limited to two studies: (1) Cave divers have explored and surveyed Phantom Lake Spring Cave upstream for $1.4 \mathrm{~km}$ northwest of the entrance and $\sim 500 \mathrm{~m}$ downstream to the south, for a total surveyed length of $3075 \mathrm{~m}$. The cave continues unexplored at its upstream and downstream surveyed ends. Phantom Lake Spring Cave is now the second deepest cave in Texas, and the deepest underwater cave in the US, with a depth of $140.8 \mathrm{~m}$ at the current limit of exploration (ADM Exploration Foundation, 2013). (2) In 2013 personnel with the National Cave and Karst Research Institute (NCKRI) injected uranine dye into the downgradient section of Phantom Lake Spring Cave and deployed dye detectors in all of the downgradient springs. The dye appeared in the pool at Balmorhea State Park six days later. Dye was not detected at any of the other springs or at any of the four monitored wells, suggesting little inflow from other sources into the cave stream between the dye injection point and San Solomon Spring. This study unequivocally demonstrated that groundwater flows downgradient through the cave to San Solomon Spring in Balmorhea State Park at a minimum velocity of about $1 \mathrm{~km} /$ day (Veni, 2013). 
In April 2019, NCKRI personnel began conducting electrical resistivity (ER) surveys over mapped portions of Phantom Lake Spring Cave to establish the resistivity signature of the cave. These geophysical surveys are part of a larger investigation of the regional hydrologic framework associated with the San Solomon Spring system. The cave map is confidential to prevent vandalism or drilling into the cave to exploit water resources contained therein. For this reason we are not including a location map of the ER surveys over the cave.

\section{Methods}

ER surveys are a common and effective geophysical method for detection of subsurface voids (e.g., Land and Veni, 2012; Land, 2013; Land et al., 2018). The basic procedure involves generating a direct current between two metal electrodes (stainless steel stakes) implanted in the ground, while measuring the ground voltage between two other implanted electrodes. Given the current flow and voltage drop between the electrodes, differences in subsurface electrical resistivity can be determined and mapped. Modern resistivity surveys employ an array of multiple electrodes connected with electrical cable. Over the course of a survey, pairs of electrodes are activated by means of an electromechanical switchbox and a resistivity meter. The depth of investigation for a typical ER survey is approximately one-fifth the length of the array of electrodes.

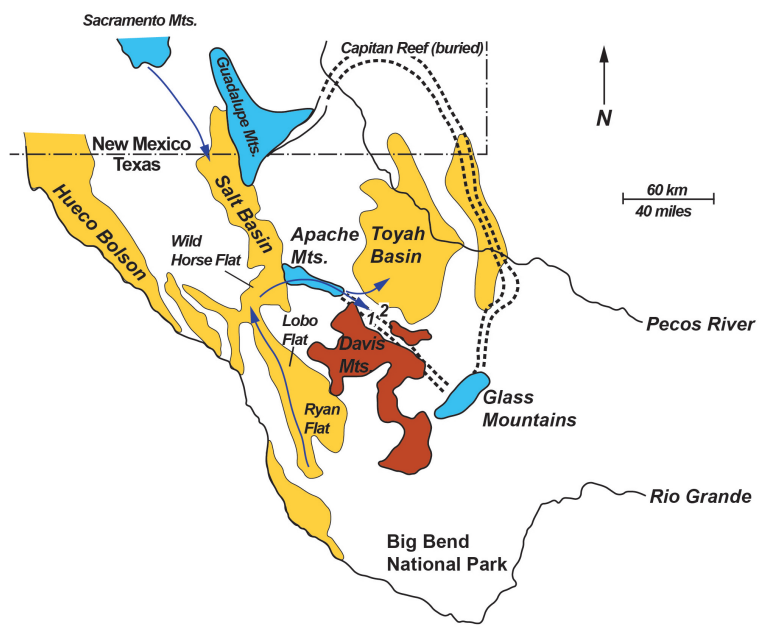

Figure 2. Regional groundwater flow systems in West Texas. Modified from Sharp (2001). 1 = Phantom Lake Cave; 2 = San Solomon and downgradient associated springs. Arrows indicate regional groundwater flow paths. Tan shading indicates Quaternary basin fill; brown shading indicates igneous and volcanic rock; blue shading represents carbonate outcrops. Dashed lines show subsurface extent of the Capitan Reef (from Land and Veni, 2018).

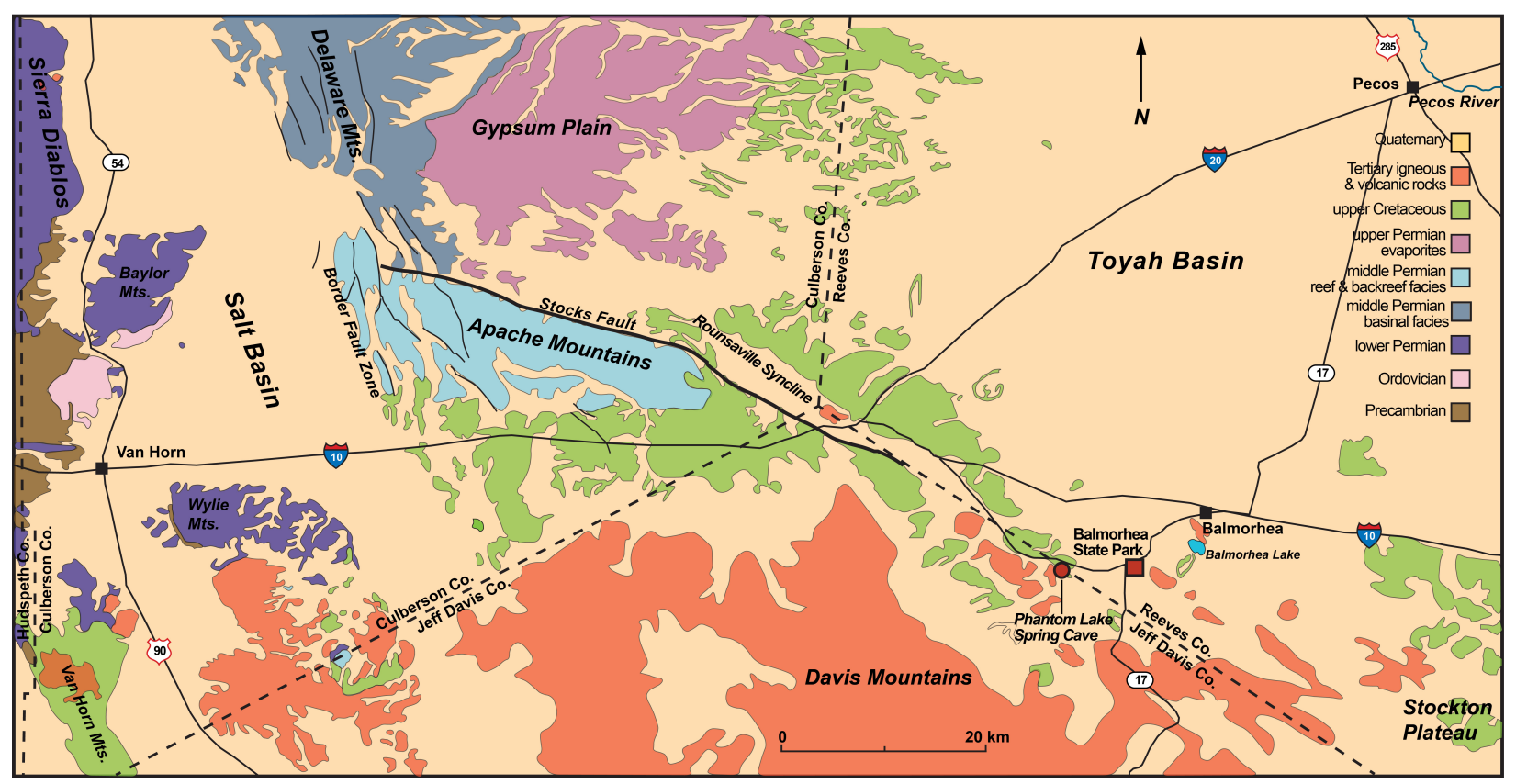

Figure 3. Generalized geologic map of the Pecos-Van Horn region of West Texas (from Land and Veni, 2018). 
We use a SuperSting ${ }^{\text {TM }}$ R8/IP electrical resistivity system provided by Advanced Geosciences, Inc. (AGI) to collect resistivity data, powered by two deep-cycle lead-acid batteries and employing a dipole-dipole array configuration. Rollalong methods were used at some sites to extend the length of the survey lines (e.g., Land and Asanidze, 2015; Land et al., 2018). During rollalong surveys, after data are collected using the initial array of electrodes, the lower half of the array is shifted forward to the far end for a $50 \%$ overlap. Although this method does not increase the depth of investigation, it permits a seamless ER profile much longer than the length of the main array.

While resistivity data are collected, a Topcon GR3 $3^{\mathrm{TM}}$ GPS instrument package is used to collect survey-grade GPS coordinates for each electrode in the array. Elevation data collected during these surveys are used to correct the resistivity data for variations in topography at each survey site. ER data are processed using EarthImager-2D ${ }^{\text {TM }}$ software. The EarthImager software chooses a resistivity scale designed to highlight natural conditions in the subsurface, thus resistivity profiles from a given survey area may not have the same resistivity scale. AGI technical staff report that, in general, it is not advisable to force the software to adhere to a specific scale, and attempts to do so may yield misleading results.

Resistivity profiles illustrate vertical and lateral variations in subsurface resistivity. The presence or absence of electrically conductive water or water-saturated soil or bedrock is one of the most significant factors influencing the results of an ER survey. Air- or water-filled caves and conduits in the survey area will thus display as zones of higher or lower resistivity, respectively, on ER profiles relative to the surrounding bedrock.

\section{Results and Discussion Phantom Lake Spring Cave ER surveys}

Most of the mapped portion of Phantom Lake Spring Cave is partially or completely flooded (ADM Exploration Foundation, 2013). Discharge from the cave has diminished in recent years and now rarely flows from the cave entrance. The US Bureau of Reclamation pumps water from inside the cave into a refugium pool, which flows over a small dam back into the cave, to provide habitat for endangered species of fish and invertebrates at that location (Figure 4; Veni, 2013). Measurements of water quality in the refugium pool using a YSI ${ }^{\mathrm{TM}}$ multiparameter meter indicate that water in the cave is slightly brackish, with a specific conductance of $3591 \mu \mathrm{S} / \mathrm{cm}$ and total dissolved solids (TDS) content of $\sim 2300 \mathrm{mg} / \mathrm{l}$. The cave passage thus displays on ER profiles as a zone of low electrical resistivity.

We used the confidential map of the cave to determine the locations of our 2D ER survey lines. All of the resistivity arrays deployed over Phantom Lake Spring Cave and its extensions were oriented roughly perpendicular to the underlying cave passage, with their center points located over the mapped cave.

ER survey line PLC1 is located $\sim 110 \mathrm{~m}$ west and upgradient of the cave entrance. This survey employed a 56 electrode dipole-dipole array with 3-m electrode spacing and achieved an exploration depth of $\sim 40 \mathrm{~m}$. According to the cave map, the main, fully flooded passage is beneath electrodes 23 and 24, at an elevation of $1053 \mathrm{~m}$, which coincides with a broad zone of low resistivity between electrodes 18 and 29 on the ER profile (Figure 5). Another low resistivity anomaly is present between electrodes 32 and 41. That feature may be an unsurveyed, water-filled conduit with no known physical connection

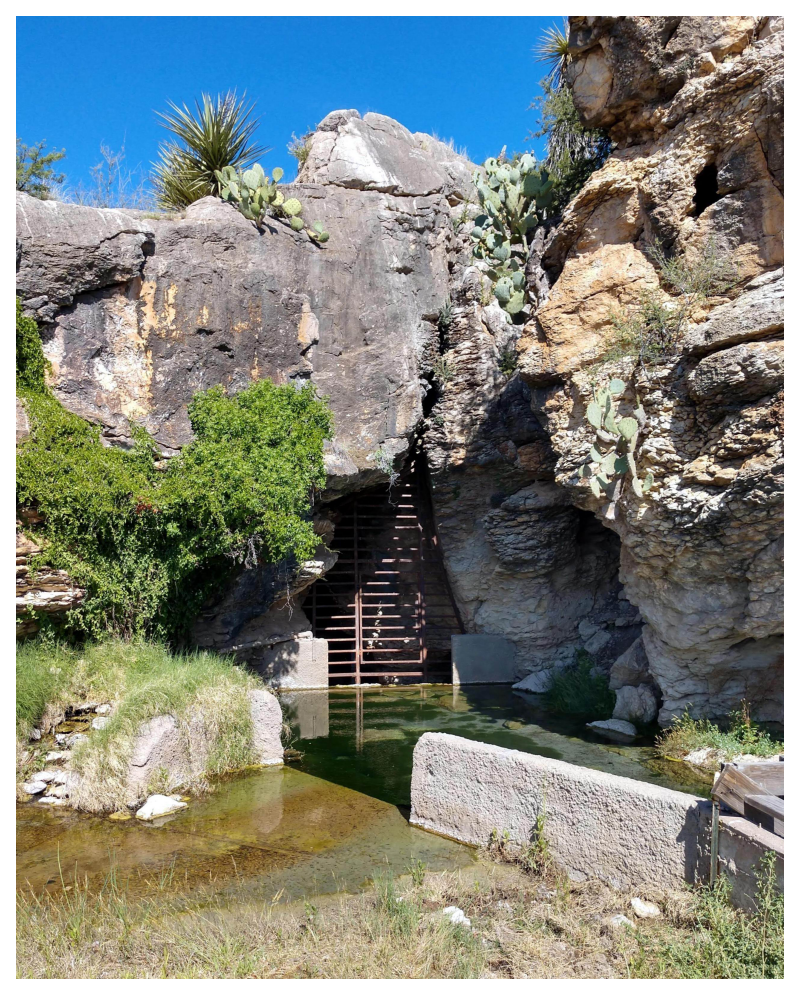

Figure 4. Gated entrance to Phantom Lake Spring Cave, formed in upper Cretaceous Buda Limestone. 
to the explored cave, although one known passage that has not been explored may link to this probable conduit.

Line PLC2 also employed a 56 electrode dipole-dipole array at $3 \mathrm{~m}$ electrode spacing, with an exploration depth of $\sim 40 \mathrm{~m}$. Line PLC2 is located $\sim 250 \mathrm{~m}$ northwest of PLC1 and $360 \mathrm{~m}$ from the cave entrance. This upgradient portion of the cave passage trends northwest from the entrance for more than a kilometer, but at one point makes a short bend to the northeast. PLC2 runs parallel to that northeast bend in the passage. The cave geometry at this station displays as a concentrated pod of low resistivity, with a conductive section extending to the northeast (Figure 6).

Lines PLC1 and PLC2 both show a shallow zone of low resistivity dipping down from the land surface to the south, west of the cave (Figures 5 and 6). We interpret this phenomenon to be caused by groundwater flowing downdip along bedding planes into the shallow subsurface. The survey area is located on the northeast limb of the Rounsaville Syncline, where the upper Cretaceous Buda limestone dips to the southwest (Figure 3). The southwest dip is clearly visible in the bedrock outcrop at both survey areas.

Line PLC4 is located over the downgradient portion of the cave passage, $\sim 280 \mathrm{~m}$ south of the cave entrance. This portion of the cave is described by the cave diving team as a much narrower passage with strong flow. The PLC4 survey also employed a 56 electrode dipole-dipole array at $3 \mathrm{~m}$ electrode spacing, achieving an exploration depth of $\sim 36 \mathrm{~m}$. The data quality from this survey is much noiser than measurements made over the upgradient portion of the cave, with an RMS error of $32.03 \%$. The poor data quality may be due to the fact that the survey was conducted over exposed limestone bedrock, and it was necessary to drill holes in the bedrock for installation of the electrodes. The ER profile nonetheless shows a small conductive zone $\sim 12 \mathrm{~m}$ below ground level (bgl) beneath electrode 28 , coincident with the mapped cave passage (Figure 7).

ER line PLC6 is located downgradient and $\sim 490 \mathrm{~m}$ from the cave entrance. The survey is also located $\sim 50 \mathrm{~m}$ south of the southernmost mapped station on the cave map.

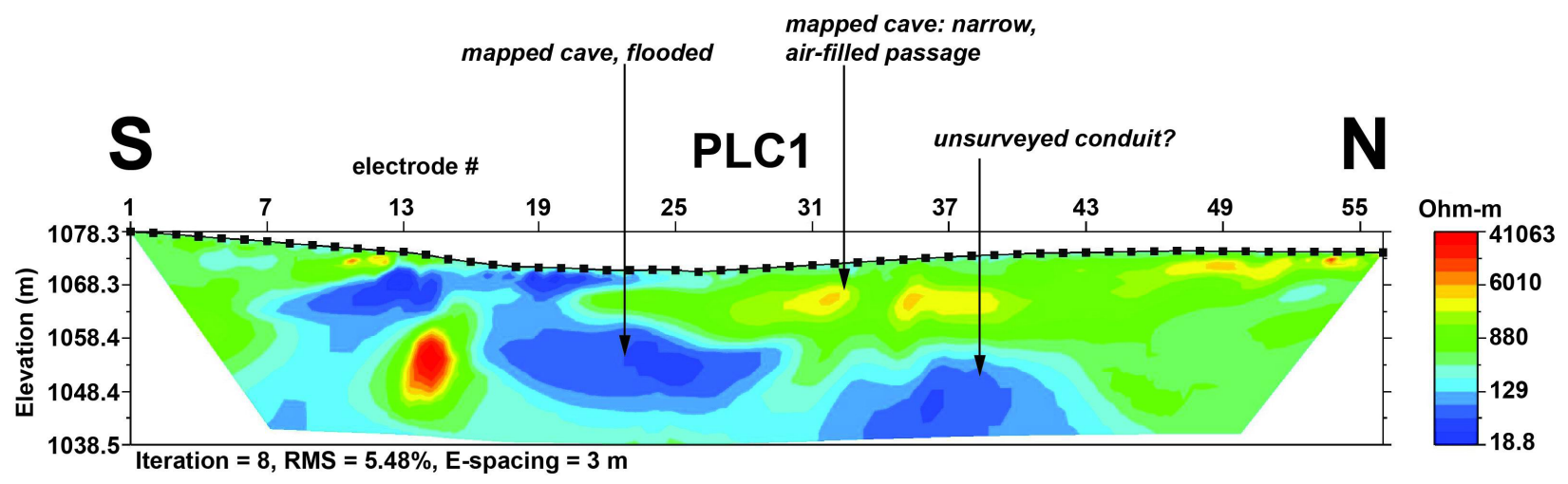

Figure 5. ER line PLC1, located upgradient from, and $\sim 110 \mathrm{~m}$ west of the cave entrance.

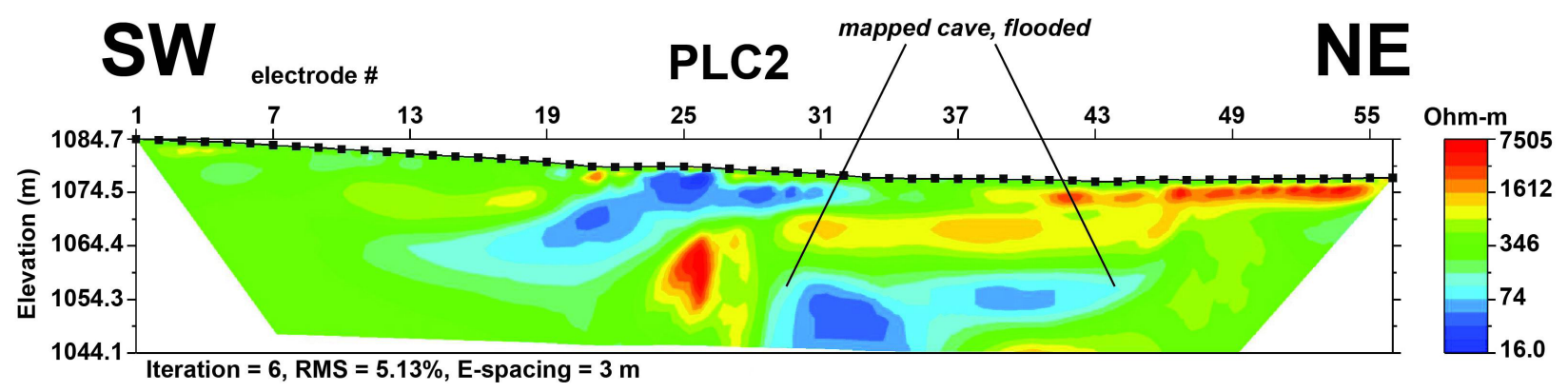

Figure 6. ER line PLC2, located upgradient from, and $\sim 360 \mathrm{~m}$ northwest of the cave entrance. 
Because of uncertainty about the depth and diameter of the cave passage at this location, we used a 70 electrode dipole-dipole array, but decreased the electrode spacing to two meters to more effectively resolve the smaller cave passage.

The eastern half of the PLC6 array was located on exposed limestone bedrock, where it was again necessary to drill holes in the rock for installation of the electrodes. The western half of the array was located on alluvium in a dense thicket of mesquite. These challenging field conditions probably account for the very noisy data set, with an RMS error $>28 \%$ (Figure 8 ). Despite the poor quality of the data, we nevertheless achieved an exploration depth of $33 \mathrm{~m}$ and succeeded in identifying a low resistivity anomaly between electrodes 36 and 43, 12 m bgl, which we assume corresponds to a southerly extension of the cave passage. The surface and near-surface geology are also clearly indicated on the ER profile. A layer of very high resistivity beneath the east half of the survey line can be seen dipping down to the west, reflecting the surface outcrop of the Buda limestone dipping down into the subsurface beneath the west half of the line. The orientation of the conductive zone, also dipping a few degrees to the west, suggests that the passage geometry may be influenced by southwest-dipping bedding planes in the Buda Limestone.
ER line PLC 8 is located $\sim 850 \mathrm{~m}$ south-southeast of the cave entrance, and employed an 84 electrode dipole-dipole array at $2 \mathrm{~m}$ spacing. This survey is $\sim 450 \mathrm{~m}$ south of the southernmost mapped station in the cave. We chose this array configuration to increase our exploration depth without sacrificing resolution, because of uncertainties about the depth, orientation and diameter of the cave passage.

The PLC8 survey achieved a $41 \mathrm{~m}$ depth of investigation with a relatively low RMS error of $12.3 \%$. This low RMS error probably reflects the fact that the survey line was deployed on alluvium substrate, where the Buda limestone is no longer exposed at the surface. The most distinctive feature on the ER profile is an elongate zone of low resistivity between electrodes 22 and 55, $\sim 12 \mathrm{~m}$ bgl (Figure 9). This geometry suggests that line PLC8 may have crossed the cave passage at an oblique angle as it begins to turn to the northeast.

\section{Giffin and San Solomon springs ER surveys}

During June and August 2019, NCKRI personnel conducted ER surveys in the vicinity of Giffin and San Solomon springs. Giffin Spring is located 200 m northwest of Balmorhea State Park. From 1953 to 2001 Giffin Spring had an average discharge of $112 \mathrm{~L} / \mathrm{s}$, the second greatest spring flow in the San Solomon Spring Group

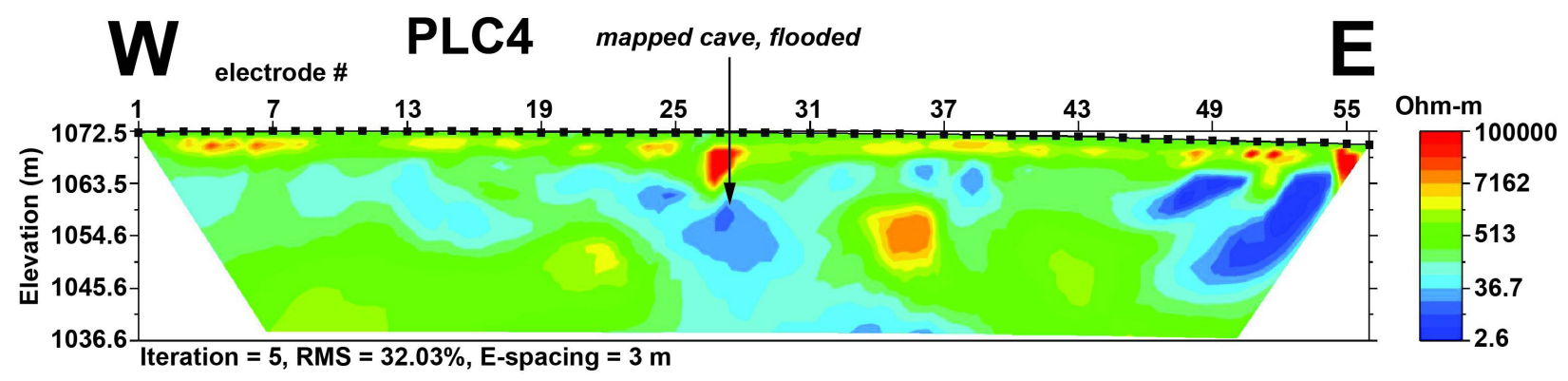

Figure 7. ER line PLC4, located downgradient from, and $280 \mathrm{~m}$ south of the cave entrance.

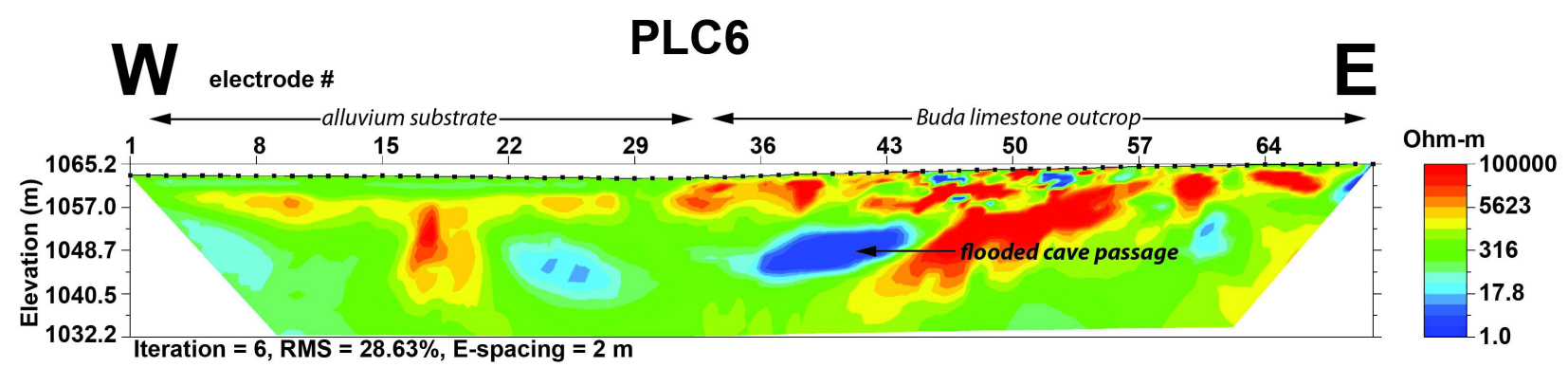

Figure 8. ER line PLC6, located downgradient, and $\sim 490 \mathrm{~m}$ south of the cave entrance. 
(Ridgeway et al., 2005). San Solomon Spring is the highest volume spring of the San Solomon Spring Group, discharging at an average rate of $\sim 850 \mathrm{~L} / \mathrm{s}$ (30 cfs) directly into the swimming pool within the park boundaries (Figure 10).

Most of the Giffin and San Solomon Spring surveys employed 112 electrode dipole-dipole arrays at $2 \mathrm{~m}$ electrode spacing, achieving an exploration depth of 45$58 \mathrm{~m}$ below ground level. Rollalong methods were used at most of the sites to extend the length of the survey lines. RMS error for all of the surveys was $<10 \%$.

ER survey SS1 was conducted $\sim 400 \mathrm{~m}$ west of Balmorhea State Park along the west shoulder of the southbound portion of Highway 17 (Figure 10). The survey employed a 112 electrode dipole-dipole single deploy- ment array (no rollalong) with $2 \mathrm{~m}$ electrode spacing. The most distinctive features of the SS1 profile are several pods of low resistivity below $980 \mathrm{~m}$ elevation (Figure 11), suggesting the presence of at least three discrete conduits flooded with brackish water formed in more resistive host rock.

ER survey SS2 employed a 112 electrode dipole-dipole array at $2 \mathrm{~m}$ electrode spacing with two rollalongs, for a total survey length of $446 \mathrm{~m}$, achieving an exploration depth of $56 \mathrm{~m}$. The SS2 array was deployed parallel to a dirt road extending southeast to northwest, immediately west of Balmorhea State Park (Figure 10). Several pods of low resistivity below $\sim 995 \mathrm{~m}$ elevation indicate conduits in the limestone bedrock flooded with brackish water (Figure 12). A shallow layer of higher resistivity, indicated by yellow and orange shading, probably rep-

\section{SW}

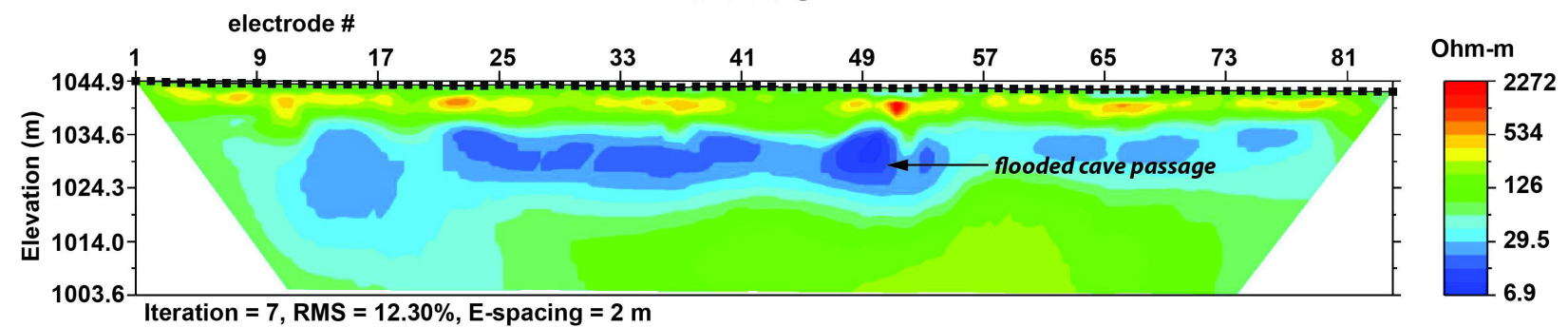

Figure 9. ER line PLC8, located downgradient and $\sim 850 \mathrm{~m}$ SSE of the cave entrance.

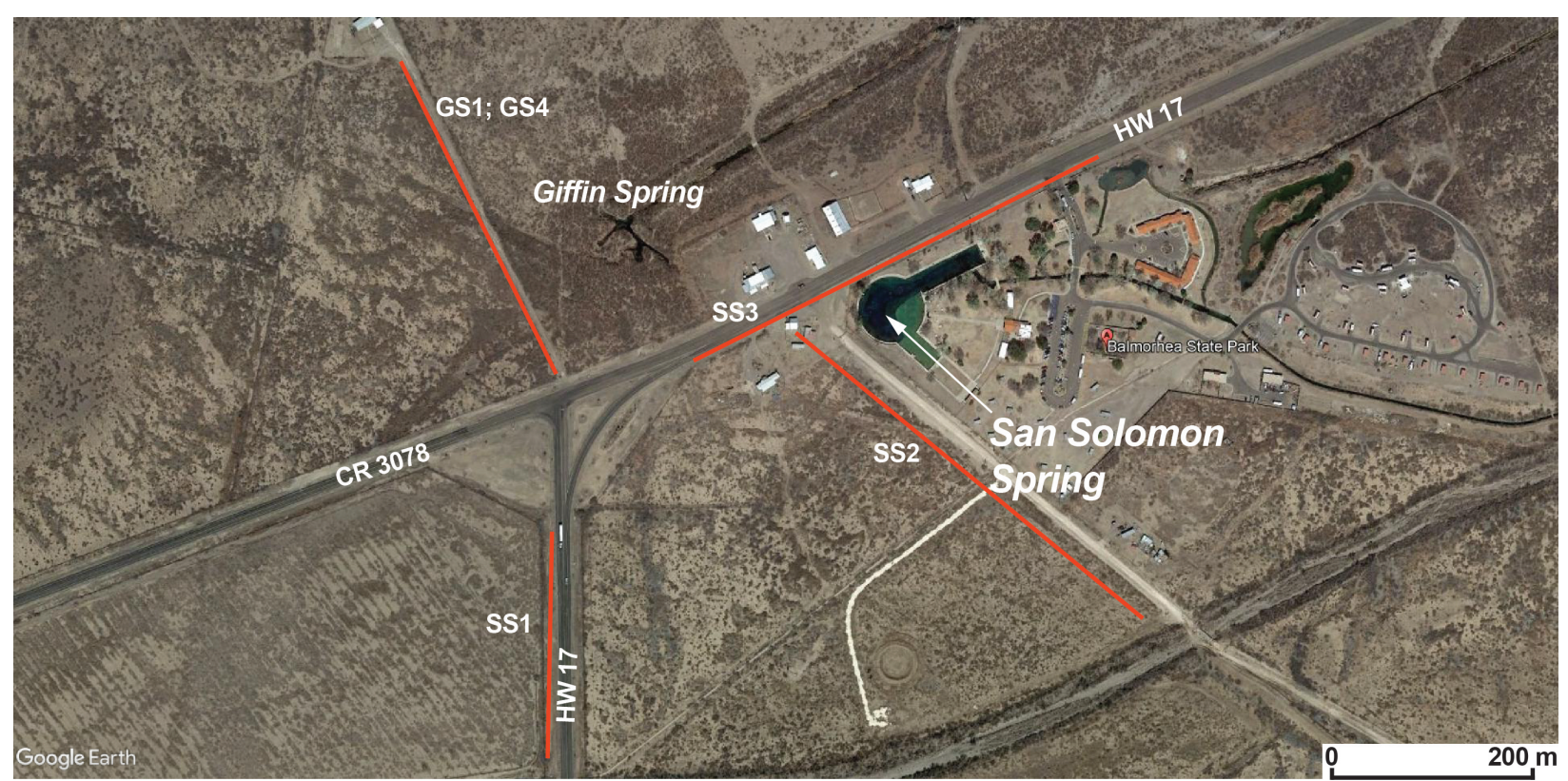

Figure 10. ER surveys conducted near Giffin and San Solomon Springs (red lines). 
resents unsaturated alluvium. If that is the case, the SS2 record suggests a variable thickness of alluvium overlying an irregular bedrock surface.

ER survey SS3 also employed a 112 electrode dipoledipole array at $2 \mathrm{~m}$ electrode spacing with two rollalongs, for a total survey length of $446 \mathrm{~m}$, achieving an exploration depth of $58 \mathrm{~m}$. The SS3 array was deployed along the south shoulder of eastbound Highway 17 , immediately adjacent to the north boundary fence at Balmorhea State Park (Figure 10). A zone of low resistivity between electrodes 85 and 110 is
$<30 \mathrm{~m}$ north of the spring outlet beneath the pool diving board in the park.

As with all of the previous surveys near the park, an irregular zone of low resistivity is visible below $\sim 995 \mathrm{~m}$ elevation (Figure 13), including several low resistivity pods indicative of flooded conduits. The record also suggests upward leakage of brackish water from these conduits into near-surface alluvium.

ER survey GS1 was conducted along a dirt road extending north-northwest from Highway 17. The survey line

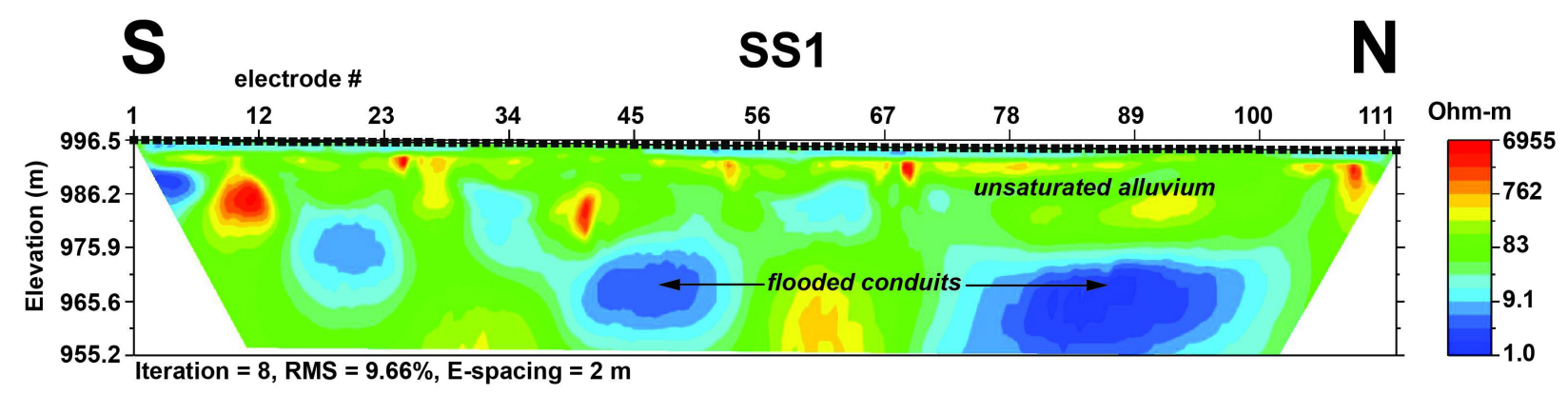

Figure 11. ER profile SS1, located $\sim 400 \mathrm{~m}$ west of the pool at Balmorhea State Park (Figure 10).
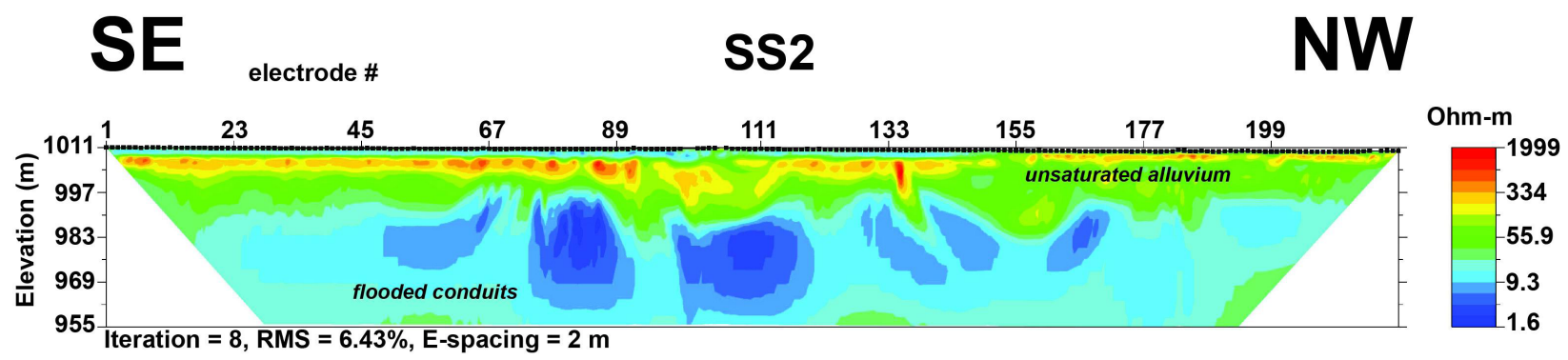

Figure 12. ER profile SS2. The low resistivity pod beneath electrode 165 is $\sim 40 \mathrm{~m}$ southwest of the southern arm of the pool at Balmorhea State Park (Figure 10).

SW

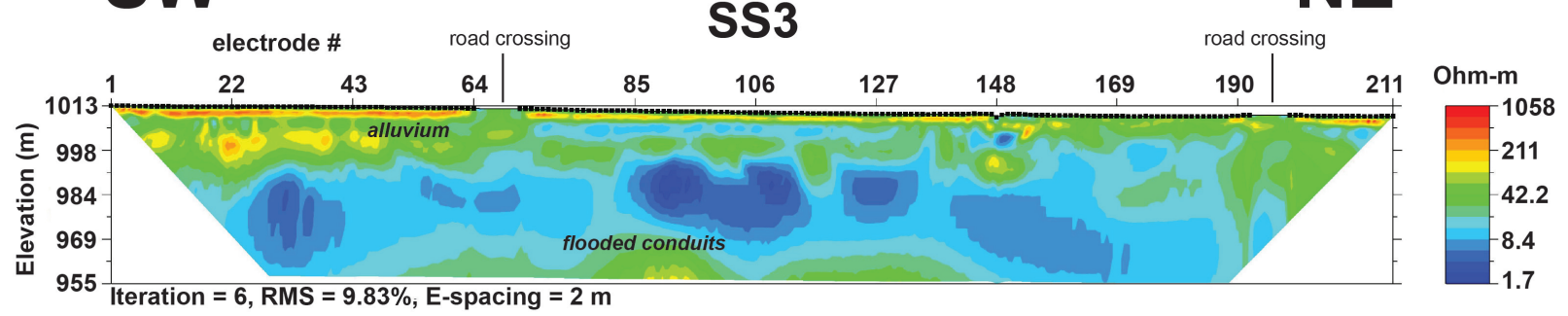

Figure 13. ER profile SS3, conducted along the SW-NE section of Highway 17 immediately adjacent to Balmorhea State Park (Figure 10). Several electrodes had to be skipped in this survey because of two road crossings. The low resistivity zone centered beneath electrode 90 is $\sim 23 \mathrm{~m}$ north of the spring outlet below the pool diving board. 
is located 100-200 m west of Giffin Spring, across the highway north from Balmorhea State Park (Figure 10). GS1 employed a 112 electrode dipole-dipole array at $2 \mathrm{~m}$ electrode spacing, with one rollalong for a total survey length of $334 \mathrm{~m}$ and an exploration depth of $46 \mathrm{~m}$. Three days later we reoccupied the site and conducted a second survey (GS4), using a 112 electrode single deployment array (no rollalong) at $3 \mathrm{~m}$ electrode spacing, thus increasing our exploration depth to $\sim 82 \mathrm{~m}$, although sacrificing some resolution relative to the $2 \mathrm{~m}$ spacing conducted earlier. The GS1 and GS4 surveys coincide precisely with each other and are both $334 \mathrm{~m}$ long.

The most distinctive features of the GS1 profile are a near-surface layer of relatively high resistivity extending to $\sim 12 \mathrm{~m} \mathrm{bgl}$, and an irregular zone of lower resistivity below $\sim 995 \mathrm{~m}$ elevation (Figure 14A). The shallow higher resistivity layer probably represents air-filled porosity in unsaturated alluvium (yellow-orange shading) and possibly bedrock (green shading). The lower resistivity layer, shown in shades of blue and ranging from 2 to $20 \mathrm{ohm}-\mathrm{m}$, probably indicates flooded conduits and brackish water-saturated bedrock formed below the water table. The low resistivity zone near the north end of the profile has a distinctive vertical fabric, which may reflect solution-enlarged vertical fractures formed in the Buda Limestone.

The low resistivity features visible on the GS1 profile are also apparent on GS4 (Figure 14B). It is worth noting that the layer of low resistivity does not extend down to the bottom of the profile, as we might expect with the saturated zone in a more conventional sand/gravel aquifer, but is confined to a discrete layer between 970 and $1000 \mathrm{~m}$ elevation. We interpret this phenomenon to indicate a karstified layer with solution-enlarged conduits in the uppermost $30 \mathrm{~m}$ of the Buda Limestone, through which groundwater is flowing east toward Giffin Spring.

Thickness of the alluvial layer overlying the limestone bedrock is an important question about the study area that remains unanswered. The lithologic log from a water well located $1.5 \mathrm{~km}$ south-southwest of the park reports an alluvial thickness of $120 \mathrm{~m}$ overlying limestone

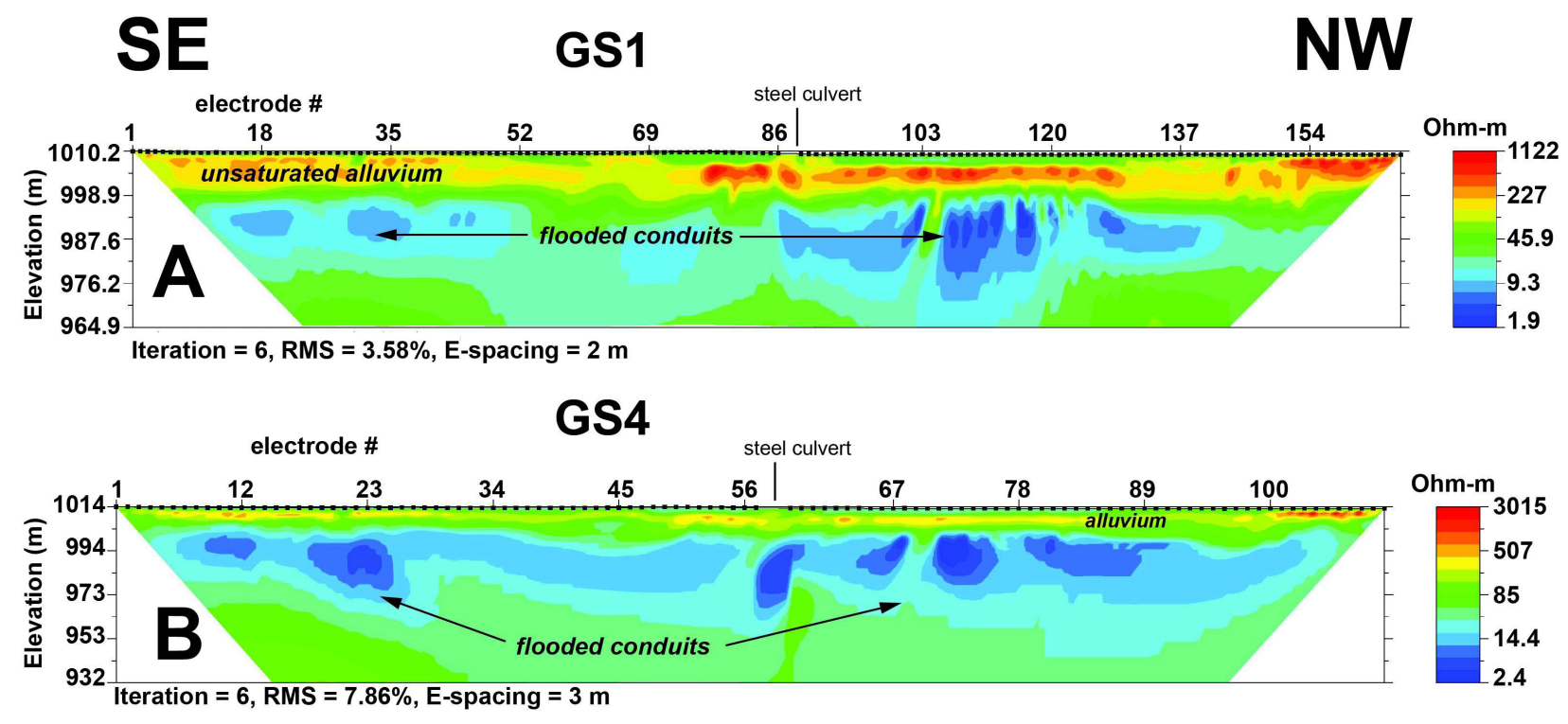

Figure 14A. ER profile GS1, showing results of a 112 electrode dipole-dipole rollalong survey (one roll) at $2 \mathrm{~m}$ electrode spacing. The low resistivity zone beneath electrode 35 is $\sim 100 \mathrm{~m}$ WSW of Giffin Spring.

Figure 14B. ER profile GS4, same location as GS1, showing results of a 112 electrode dipole-dipole single-deployment array (no rollalong) at $3 \mathrm{~m}$ electrode spacing. The low resistivity anomaly beneath electrode 23 coincides with the low resistivity zone beneath E35 on GS1. Both profiles are $334 \mathrm{~m}$ long. 
bedrock. By contrast, a well located $1.3 \mathrm{~km}$ west of the park reports water in Cretaceous limestone at a depth of only $23 \mathrm{~m}$.

The results of these ER surveys are consistent with known or likely hydrogeologic conditions. The surveys over known portions of Phantom Lake Spring Cave clearly illustrate the cave at its known depth and location. Surveys over unexplored downgradient areas along the cave's projected route reveal probable conduits consistent with the likely extent and position of the continuation of the cave.

The ER surveys adjacent to Giffin and San Solomon springs indicate distributary flow patterns, which are common at some karst springs (Veni, 2012). When alluvium restricts flow through the initially-formed spring conduit, groundwater backs up and is diverted under higher pressure into adjacent fractures and bedding planes, enlarging them into conduits that discharge through new nearby springs. Leakage of groundwater into alluvium near the springs and the alluvium-bedrock contact are apparently observable, awaiting verification by proposed drilling.

The distributary conduit network around Giffin and San Solomon springs requires further study. The close proximity of these conduits suggests probable mixing of groundwater from the sources of each spring, while dye tracing data to date suggest no mixing occurs.

\section{Conclusions}

The San Solomon Spring Group is one component of an extensive and underinvestigated karstic aquifer system in West Texas. Electrical resistivity surveys have been shown to be an effective tool for characterizing flooded cave passages and karst springs that make up this regional aquifer, in an area where there are few wells or other subsurface information available. The results of this study will thus provide important information about the downgradient end of a regional groundwater flow system originating over 120 kilometers to the west. This investigation will also provide hydrogeologic context for any impacts on water resources or water quality associated with oil and gas extraction in the region.

\section{Acknowledgements}

Funding for this investigation has been provided by Apache Corporation. Field assistance was provided by personnel with the New Mexico Bureau of Geology and Mineral Resources, and a student from Sul Ross University. The authors wish to acknowledge the support of the US Bureau of Reclamation, the Texas Department of Transportation, and several private landowners who provided access to their property and lands they administer.

\section{References}

ADM Exploration Foundation. 2013. Phantom Cave 2013 exploration: Magnus Hall, the Desolate Abyss: http://www.admfoundation.org/projects/ phantomcave2013/phantom2013.html (accessed 26 September, 2017).

Anaya R. 2001. An overview of the Edwards-Trinity Aquifer system, central-West Texas. In: Mace RE, Mullican WF III, Angle ES, editors. Aquifers of West Texas, chapter 9. Texas Water Development Board Report 356. Austin (TX): Texas Water Development Board, p. 100-119.

Anaya R, Jones I. 2009. Groundwater availability model for the Edwards-Trinity (Plateau) and Pecos Valley aquifers of Texas. Texas Water Development Board Report 373, 103 p.

Barker RA, Bush PW, Baker ET Jr. 1994. Geologic history and hydrogeologic setting of the EdwardsTrinity Aquifer system, west-central Texas. US Geological Survey Water-Resources Investigations Report 94-4039, 48 p.

Barker RA, Ardis AF. 1996. Hydrogeologic framework of the Edwards-Trinity Aquifer system, westcentral Texas. US Geological Survey Professional Paper 1421-B, $61 \mathrm{p}$.

Blackmon D. 2016 September 8. Apache's Alpine High discovery defies conventional wisdom. Forbes Magazine. Available from: https://www.forbes. com/sites/davidblackmon/2016/09/08/apachesalpine-high-discovery-defies-conventionalwisdom/\#7b9a92d0e127.

Bumgarner JR, Stanton GP, Teeple AP, Thomas JV, Houston NA, Payne JD, Musgrove M. 2012. A conceptual model of the hydrogeologic framework, geochemistry, and groundwater-flow system of the Edwards-Trinity and related aquifers in the Pecos County region, Texas. US Geological Survey Scientific Investigations Report 20125124, 74 p. 
Chowdhury AH, Ridgeway C, Mace RE. 2004. Origin of the waters in the San Solomon Spring system, Trans-Pecos, Texas. In: Mace RE, Angle ES, Mullican WF, editors. Aquifers of the Edwards Plateau, chapter 17. Texas Water Development Board Report 360.

Kastning EH Jr. 1983. Geomorphology and hydrogeology of the Edwards Plateau karst, central Texas. [PhD dissertation]. The University of Texas at Austin, 657 p.

Kuniansky EL, Holligan KQ. 1994. Simulations of flow in the Edwards-Trinity Aquifer system and contiguous hydraulically connected units, westcentral Texas. US Geological Survey WaterResources Investigations Report 93-4039, 40 p. + 3 pls.

Kuniansky EL, Ardis AF. 2004. Hydrogeology and ground-water flow in the Edwards-Trinity Aquifer system, west-central Texas. US Geological Survey Professional Paper 1421-C, 78 p.

LaFave JI, Sharp JM Jr. 1987. Origins of ground water discharging at the springs of Balmorhea. West Texas Geological Society Bulletin 26: 5-14.

Land L. 2013. Evaporite karst in the Permian Basin region of west Texas and southeastern New Mexico: The human impact. In: Land L, Doctor DH, Stephenson JB, editors. Proceedings of the Thirteenth Multidisciplinary Conference on Sinkholes and the Engineering and Environmental Impact of Karst, Carlsbad, New Mexico. National Cave and Karst Research Institute Symposium 2. Carlsbad (NM): National Cave and Karst Research Institute. p. 113-121.

Land L, Veni G. 2012. Electrical resistivity surveys of anthropogenic karst phenomena, southeastern New Mexico. New Mexico Geology 34 (4): $117-125$.

Land L, Asanidze L. 2015. Rollalong resistivity surveys reveal karstic paleotopography developed on near-surface gypsum bedrock. In: Doctor DH, Land L, Stephenson JB, editors. Proceedings of the Fourteenth Multidisciplinary Conference on Sinkholes and the Engineering and Environmental Impact of Karst, Rochester, Minnesota. National Cave and Karst Research Institute Symposium
5. Carlsbad (NM): National Cave and Karst Research Institute, p. 365-370.

Land L, Veni G. 2018. Karst hydrogeology scoping investigation of the San Solomon Spring area: Culberson, Jeff Davis, and Reeves Counties, Texas. National Cave and Karst Research Institute Report of Investigation 8, Carlsbad, New Mexico.

Land L, Cikoski CK, Veni G. 2018. Sinkholes as transportation and infrastructure geohazards in mixed evaporite-siliciclastic bedrock, southeastern New Mexico. In: Sasowsky ID, Byle MJ, Land L, editors. Proceedings of the Fifteenth Multidisciplinary Conference on Sinkholes and the Engineering and Environmental Impact of Karst, Shepherdstown, WV. National Cave and Karst Research Institute Symposium 7. Carlsbad (NM): National Cave and Karst Research Institute. p. $367-377$.

Mace RE, Mullican III WF, Angle ES, editors. 2001. Aquifers of West Texas. Texas Water Development Board Report 356. Austin (TX): Texas Water Development Board.

Ridgeway C, Austin B, Boghici R, Chowdhury A, Christian B, Coker D, Mace R, Mathews R, Schuster S, Smith R, Watson W. 2005. Diminished spring flows in the San Solomon Springs System, Trans-Pecos, Texas. Texas Parks and Wildlife Report 84312 [unpublished].

Sharp JM Jr. 2001. Regional groundwater flow systems in Trans-Pecos Texas. In: Mace RE, Mullican WF III, Angle ES, editors. Aquifers of West Texas, chapter 4. Texas Water Development Board. Austin, Texas, p. 41-55.

Sharp JM Jr, Boghici R, Uliana M. 2003. Groundwater systems feeding the springs of West Texas. In: Garrett GP, Allan NL, editors. Aquatic fauna of the Northern Chihuahuan Desert, Special Publications, Museum of Texas Tech University 46, p. 1-11.

Thomas JV, Stanton GP, Bumgarner JR, Pearson DK, Teeple AP, Houston NA, Payne JD, Musgrove M. 2013. A conceptual hydrogeologic model for the hydrogeologic framework, geochemistry, and groundwater-flow system of the Edwards-Trinity and related aquifers in the Pecos County region, Texas. USGS Fact Sheet 2013-3024. 
Uliana MM, Banner JL, Sharp JM Jr. 2007. Regional groundwater flow paths in Trans-Pecos, Texas inferred from oxygen, hydrogen and strontium isotopes. Journal of Hydrology 334: 334-346.

US Fish and Wildlife Service. 2013. Endangered and threatened wildlife and plants; determination of endangered species status for six West Texas aquatic invertebrates. Federal Register 78 (131).

Veni G. 2012. Passages. In: White WB, Culver, DC, editors. Encyclopedia of caves. Chennai: Academic Press, p. 603-608.

Veni G. 2013. Impact of climate change on human and ecological use of karst groundwater resources: A case study from the southwestern USA. In: NCKRI Symposium 3: 20th National Cave and Karst Management Symposium, p. 51-59. 